\title{
Assessment of the forest landscape along selected motor vehicle routes
}

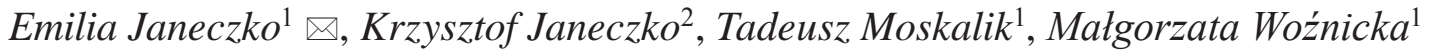 \\ ${ }^{1}$ Warsaw University of Life Sciences, Faculty of Forestry, Department of Forest Utilization, Nowoursynowska 159, \\ 02-776 Warsaw, Poland, phone: 4822 5939134, e-mail: janeczko.emilia@gmail.com \\ ${ }^{2}$ Warsaw University of Life Sciences, Faculty of Forestry, Department of Forest Management Planning, Geomatics and \\ Forest Economics, Nowoursynowska 159, 02-776 Warsaw, Poland
}

\section{Abstract}

This paper presents the results of research that aims to analyse and evaluate the attractiveness of the forest landscape in the vicinity of selected motor vehicle routes that differ in terms of technical parameters, such as motorways, regional roads and local (municipal) roads. The diversity of landscape units was used as the measure of landscape attractiveness. Landscape diversity analysis allows to establish the details related to specific parts of the road and the options for configuring the road environment. These options relate to the way the forest is managed and mainly involve aspects of infrastructure and cultivation. They include activities such as afforestation work and rebuilding the species composition of forest stands. According to the research, the lower the technical class of a road, the greater is the need to take action to adapt the structural-tree stand system to meet the safety requirements of road users.

\section{KeY WORDS}

aesthetics landscape, landscape planning, roadways, social preferences

\section{INTRODUCTION}

The increase in society's expectations related to using the forest, expressed by a desire to limit the multiple functions of forests to one, namely, its social function (Arnberger and Haider 2005; Gundersen and Frivold 2008; Paschalis 2009), stimulates the development of research directions aiming to define the hierarchical objectives of forest management. The growing importance of the non-productive functions of the forest forces foresters to manage them in a manner that is acceptable to society. This also applies, to a significant extent, to those 'most visible' forest fragments, mainly the forests along roads and hiking trails. Hence, there is a need to work on assessing the attractiveness of forest landscapes and, related to this, the possibility of changing them.

The methods of landscape assessment can be divided into two groups: classical methods and specialised methods (Śleszyński 1997). Classical methods are based on the analysis of cartographic materials, detailed studies of the landscape, and they allow a determination to be made of the relative value of the considered elements and landscape features within the so-called reference fields (basic units). In contrast, specialised methods consist of assessing the attractiveness of the landscape on the basis of photographs, slides or videos 
presented to respondents, as well as through questionnaires. Previous studies of road-user landscape preferences (Akbar et al. 2003; Arriaza et al. 2004; Clay and Smidt 2004; Evans and Wood 1980; Sullivan 1994; Wolf 2003), however, are very general and provide basic indications for landscaping road surroundings. On the basis of the specialised landscape assessment methods, it is possible to determine only the general principles of its design. In the available literature, no research has been encountered on social preferences relating only to roads passing through forests. The preference surveys (exemplified by the work of Hammitt et al. 2004; Jensen 1993; Karjalainen and Komulainen 1999; Polat and Akay 2015; Scrinzi and Floris 2000; Tahvanainen et al. 2001; Vander Stoep and Duniavy 1992) demonstrate the many different views about the attractiveness of the forest landscape, relating to important aesthetical forest characteristics such as density and species composition. Hence, a study of social preferences can only add to classical landscape studies. The methods of analysis and evaluation of the landscape provide useful information for spatial planning and, therefore, cannot rely solely on the views and opinions of society.

In formulating modern views on the principles of developing a landscape, the issue of space perception, particularly visual perception, plays an important role. Visual perception, studies of driver errors, the information capacity of roads and models of the theory of cognition are the most popular fields of scientific research in traffic psychology. There is much documented evidence indicating the need for landscaping in the vicinity of roads in relation to the speed with which road users are moving. This is due, amongst other things, to the fact that visual perception is generally a function of time and distance (Tunnard and Pushkarev 1963). Seeing an object and recognising it largely depend on the speed of the observer's movement. On this basis, it appears that the possibilities and principles of landscaping in the vicinity of roads such as motorways, municipal roads or regional roads will be different.

The process of shaping the landscape along motor vehicle routes should include not only the roadway but also the wider roadside verge (Wójcicki 1995). These activities should be conducted throughout the area that is visually integrated with the road.

In an open landscape, for example, consisting of a mosaic of fields, meadows and woodlots, the space under analysis will be considerably more extensive than when a road passes through a dense forest. In this case, it seems appropriate to conduct the visual analyses along the road corridor, the span of which is determined by the angle of vision and the distance from the focal point defined for the average speed of travel (Janeczko 2012).

The problem of the proper landscaping of forests surrounding roads relates primarily to forests located in tourism and recreational areas, as well as in lowland areas characterised by little landscape variability. These are the first areas requiring the development of a methodological basis of assessing the forest landscape, based on the understanding of the concept as set forth in the European Landscape Convention (2000). The Convention defines this as an area whose features are the result of the action and interaction of natural elements (e.g. vegetation, topography, streams and reservoirs) and/ or human elements (e.g. roads, skid trails, tourism and recreation infrastructure). Therefore, the purpose of the study was to analyse the diversity and evaluate the forest landscape attractiveness along the selected motor vehicle routes, as well as to determine the resulting possibilities for landscaping the area.

The results of the conducted research are important in making decisions on the broadly understood process of spatial development, including forest landscaping, and in selecting forest recreation areas, as well as in assessing the non-market value of the functions of forests.

\section{MAterial AND MEthods}

Taking into account the guidelines indicated in the literature to design the research project, it was acknowledged that the study should be conducted in the vicinity of roads located in a generally lowland terrain, characterised by a well-developed road network with extensive forest cover and high landscape value. One such area in Poland is the Opole Voivodeship. The largest forest complexes in the region are the Namysłowickie Forest, Stobrawskie Forest and Niemodlińskie Forest. This area is highly valued for its specific landscape features, and as a result, approximately $27.1 \%$ of the area is legally protected in various forms. The following sections of roads passing through forests were selected as study sites:

- the A4 motorway; two sections of 9.3 and $3.6 \mathrm{~km}$ in length for a total of $12.9 \mathrm{~km}$, 
- regional road no. 454 - four sections of 2.8, 2.3, 3.9 and $0.5 \mathrm{~km}$ in length for a total of $9.5 \mathrm{~km}$,

- one municipal road - four sections of 5.2, $0.8,2.8$ and $2.5 \mathrm{~km}$ in length for a total of $11.3 \mathrm{~km}$.

The study involved a total of $33.7 \mathrm{~km}$ of roads and was carried out in public forests. The State Forests National Forest Holding, which manages publicly owned forests on behalf of the Polish State Treasury, gave permission to conduct the study on these sites. The field studies did not involve endangered or protected species.

The spatial analyses included a span with a width of approximately $400 \mathrm{~m}$ for the municipal road, $350 \mathrm{~m}$ for the regional road and $280 \mathrm{~m}$ in the case of the motorway. The span was determined on the basis of the analysis of the diagram (Bell 1997) showing the impact of velocity on the viewing angle and distance of the foreground focal point. The average speed of travel on the analysed roads was 54,68 and $118 \mathrm{~km} / \mathrm{h}$, respectively.

The main source of the empirical data required to perform the work was the Spatial Information System of State Forests (SILP), in particular the valorisation description (LAS subsystem), which contains information about forest address and selected forest stand characteristics (age, forest habitat type) and forest stand exclusion areas, digital maps with information about road routes and the surface distribution of forests in their vicinity, 1:25 000 topographic maps as well as video recordings, drawings and sketches made in the field. The registration of roads (video recording) was performed with a SONY HDR-HC3E camera from the passenger side of an automobile at variable speeds adapted to traffic regulations and local road conditions. The roads along with their surroundings were filmed at similar times each day (morning hours) in good weather conditions and relatively low traffic (weekends). Each of the roads was filmed in the same order. As the video recordings were made, GPS measurements were carried out to determine the precise position of the video camera in relation to the road depicted on the digital map. Coordinate points were measured at specific sites along the route, such as entrances and exits from the forest, as well as at intersections with local roads.

Assessing landscape values was based on the detailed analysis of the variables of the view. The first stage of the study was the identification of landscape units distinguished on the basis of terrain differences (flat land, sloping land), type of vegetation (low vegeta- tion, not exceeding $1 \mathrm{~m}$ in height, shrubs, sparse vegetation - thinly distributed arrangement of individual trees and shrubs, as well as forest stand) and the presence of surface water (occurrence of streams, reservoirs or their lack). Taking into account the spatial relations resulting from the location of the above-mentioned vegetation types along the road (both sides), the following vegetation systems were selected: forest stand-low vegetation, forest stand-shrubs, forest stand-sparse vegetation and forest stand-forest stand. Data on the distribution of individual vegetation systems, the diversity of the terrain and the presence of surface water along the road was taken from the analysis of a topographic map at a scale of 1:25 000 and a video recording. This information, verified by the digital maps of forest stands and the valorisation description, was respectively encoded in AutoCad 2007. The combination of the established vegetation systems, terrain and surface water allows 16 landscape units to be distinguished. It was assumed that the attractiveness of the forest landscape is conditioned by its diversity. The landscape value is affected by its structural diversity. The more varied a landscape, the greater is its value. The diversity of landscape units selected for the study is related to the specific characteristics of forest stands, as well as the presence of vegetation elements in the roadway verge (e.g. avenue and row of trees) and infrastructure elements (e.g. power line and guard rail). The physiognomic diversity of the forest, as evidenced by numerous studies of this issue (Janeczko 2002; Jensen 1993; Kellomäki and Savolainen 1984), is mainly conditioned by its age and species composition. Thus, it is precisely these stand qualities that are the basis for distinguishing the forest stand units. For this purpose, valorisation description data from the SLIP database were used. The spatial structure of forest stands was based on digital maps of the forest developed for the Regional Directorate of State Forests in Katowice. The analyses took into account three forest types (coniferous, deciduous and mixed) and three age groups of stands (up to 20 years old, 20-40 years old, and over 40 years old), roughly corresponding to the developmental phases of stands, which, together with their placement along the roads, made it possible to determine a total of 36 forest stand units. The spatial distribution of forest stand units was determined by importing maps with the types of forests and age groups from the ArcMap program to AutoCAD 2007. Information on both stand fea- 
tures was encoded in this program and then the codes were converted to their corresponding forest stand unit numbers in a new thematic layer. The next step in analysing the forest landscape in the vicinity of roads was to determine their structural variability (Fig. 1).

Structural variability is mainly conditioned by the presence of vegetation and/or infrastructure components in a roadside verge, having a continuous, linear character, which can be identified by motor vehicle drivers. To analyse the structure of the road and its vicinity, sketches and photographs taken during field observations and video were used. AutoCad 2007 was again used to determine the spatial distribution of the structural units. The linear range of the structural units established on the basis of speed of travel was verified using a scanned 1:25 000 topographic map and a forest digital map entered into AutoCad 2007. The information gathered enabled us to establish the scenic variability (rhythm) of the road, expressed in the form of a graph reflecting the spatial differentiation of the landscape, forest stand and structural units - selected, simply presented road features (horizontal curves, the length of straight sections, intersections). The significance of analysing road rhythm in making spatial planning decisions and designing a road's environs is presented in more detail in the publications of Forczek-Brataniec $(2007,2008)$.

This study assumes that the road itself is most important when considering safety conditions, and the influence of forest stand and scenic-structural elements neighbouring intersections is minimal. This assumption stems from the fact that $32 \%$ of all accidents on roads occur at intersections (The National Road Safety Programme GAMBIT, 2205). Those sections of road characterised by a high diversity in the scenic-structural and forest stand rhythm near intersections should have their scenic-structural or forest stand configuration adjusted. The analysis conducted allowed the attractiveness of the distinguished landscape units to be assessed. The measure of attractiveness was the rate of diversity expressed as the quotient of forest stand and structural units present within the landscape unit and its length. On the basis of the diversity coefficient values obtained, five

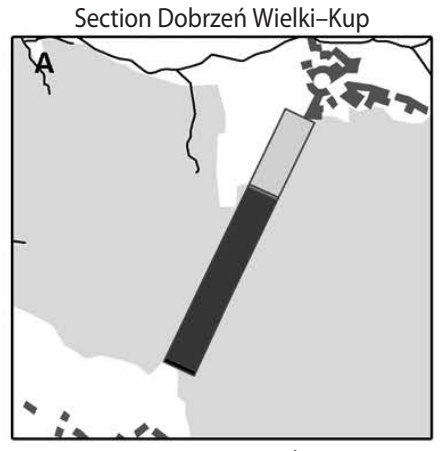

Section Kup-Ładza

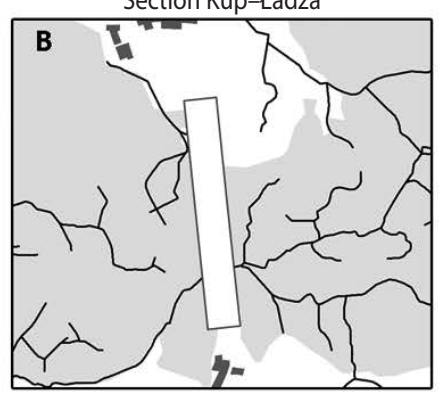

Section Krzywa Góra-Pokój

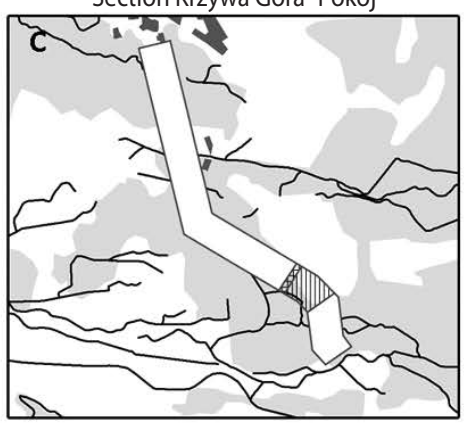

Section Pokój-Zieleniec

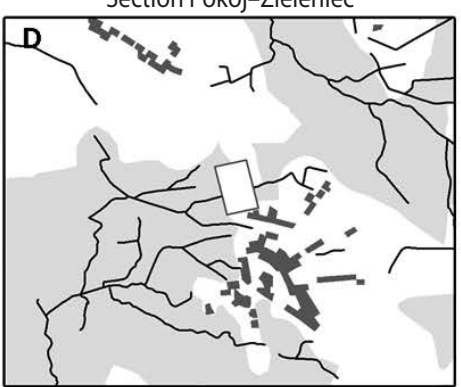

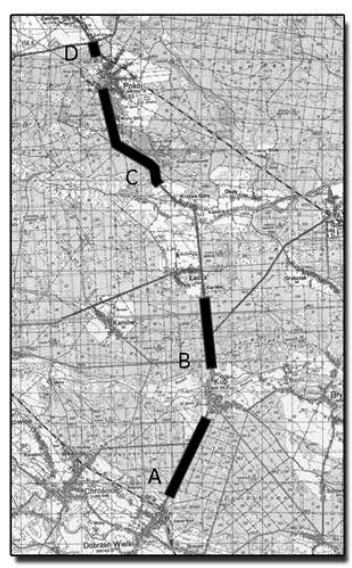

structural unit $A$ structural unit $B$ structural unit $C$

structural unit $D$ structural unit $\mathrm{E}$ structural unit $F$

而盂耑 structural unit $\mathrm{G}$

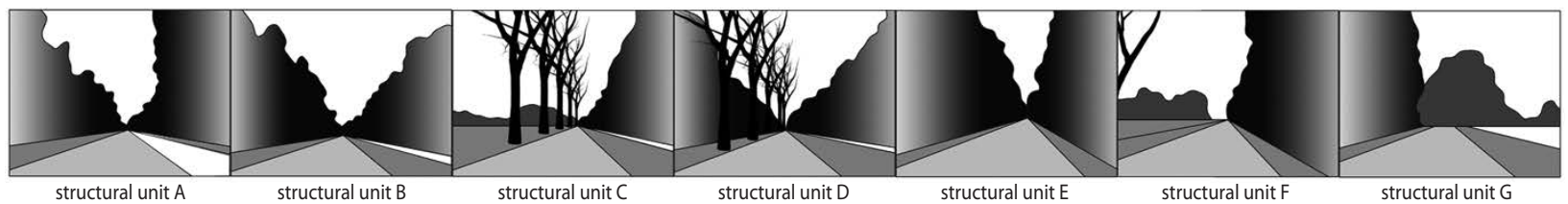

Figure 1. Identification of structural units 
classes of attractiveness were determined (very high, high, average, low and very low attractiveness), which were then presented in spatial terms. As a result, the possibility of changing the forest landscape along selected motor vehicle routes was established.

\section{Results}

Amongst analysed roads, the municipal road was characterised by the largest mosaic of landscape units (13), whilst the motorway had the smallest number (6). The area that the municipal road passes through is quite rich in different types of watercourses; moreover, it has a much more varied relief compared to the routes of the motorway or regional road. The vicinity of the remaining roads, motorway and regional, are characterised by very little difference in relief. There are practically no watercourses along the motorway, as opposed to the regional and municipal roads. Additionally, the motorway is routed mainly through a uniform, spatially compact forest, which also means that this road had a smaller number of landscape units. In terms of the tree stand characteristics along the analysed roads (tree stand units), the greatest diversity of forest habitat types was found along the motorway, as well as the municipal road. A different type of forest habitat dominated in the vicinity of each analysed road: a mixed, moist coniferous forest abuts the municipal road, a fresh mixed forest borders the motorway and a moist mixed forest runs along the regional road, with a large proportion of a mixed moist coniferous forest. In analysing the types of forests, it was found that their proportion was similar for the municipal road and motorway, where coniferous forests dominated, with deciduous forests comprising $5 \%$ of the area. The highest proportion of deciduous forest was mixed deciduous along the regional road; mixed deciduous also accounted for the lowest share of all types. In terms of age, stands along the motorway and regional road have a somewhat similar age structure. In both the cases, stands of 40 years of age dominate, with similar proportions of stands at other ages along both roads. In turn, the presence of stands up to 20 years old is much more noticeable along the municipal road, representing approximately $30 \%$ of the analysed area, compared to the regional road and motorway. In terms of the number of stand units, the regional road and mo- torway are similar, with, respectively, 14 and 15 stand units distinguished. Compared to the regional road and motorway, the municipal road had a larger number of stand units. A predominance of coniferous trees over the age of 40 years was found on both sides of the municipal road and motorway, representing, respectively, $22.4 \%$ and $26 \%$ of the area. The proportion of this type of stand surrounding the regional road is much higher, amounting to $39.6 \%$ of the analysed area.

In the analysis of the natural and infrastructural elements found along the verge (structural units), the regional road was found to be most diverse, with seven structural units enumerated. Six structural units were distinguished along the motorway and four along the municipal road. A dense wall of forest on both sides of the road and open view on one side of the road were the units present for all types of roads. Only the motorway had a unit comprised of a wall of dense forest on both sides of the road with an overpass in the foreground. The motorway was distinguished by its placement in a trench, along which is a dense forest on both sides, with an acoustic screen obscuring the view on one side of the road. For the municipal road, the unit was characterised by the presence of forest along both sides of the road with a bicycle path adjacent to the road. The structural units found only for the regional road were a forest occurring on both sides of the road, a bicycle path adjacent to the road; a forest occurring on both sides of the road, a bicycle path separated from the road by a broad strip of grass; a bicycle path separated from the road by a broad strip of grass with a dense wall of forest on one side and an open view on the other side; a forest occurring along both sides of the road with no bicycle path, preceded by a row of trees on one side of the road; and a reservoir of water adjacent to one side of the road.

Based on the analysis, it can be assumed that the structural diversity of the road is mainly associated with the presence of the accompanying infrastructure (e.g. bicycle paths and acoustic barriers) or elements of vegetation (e.g. row of trees, avenue). Roads with lower parameters, lower technical class are, in general, less equipped with additional infrastructure. Conversely, roads designed for higher speeds and of greater importance in the transportation network are more infused with infrastructure elements, engineering facilities. Hence, the structural diversity of the analysed municipal road is much lower than that of the motorway 
or regional road. In analysing the spatial distribution of these distinguished landscape, stand and structural units along the selected routes, the municipal road environment as well as the route itself was found to be characterised by high diversity. The functional diversity of the road (the so-called functional rhythm) is associated with the presence of a fairly large number of intersections (19), and horizontal curves (4). The rhythm of the road environment is not uniform. In the vicinity of several intersections, the density of scenic-structural and stand units can be clearly seen, which from the standpoint of road safety requires that the current landscape layout be corrected.

Section Dobrzeń Wielki-Kup

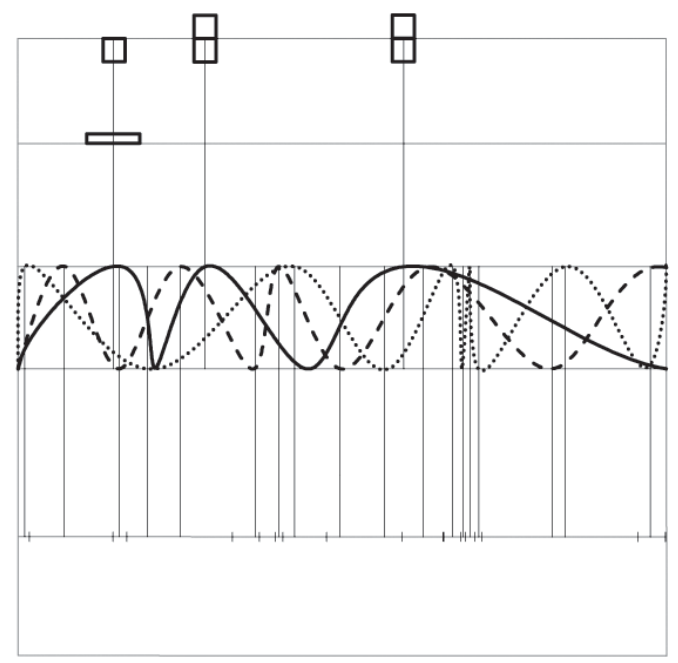

Section Krzywa Góra-Pokój

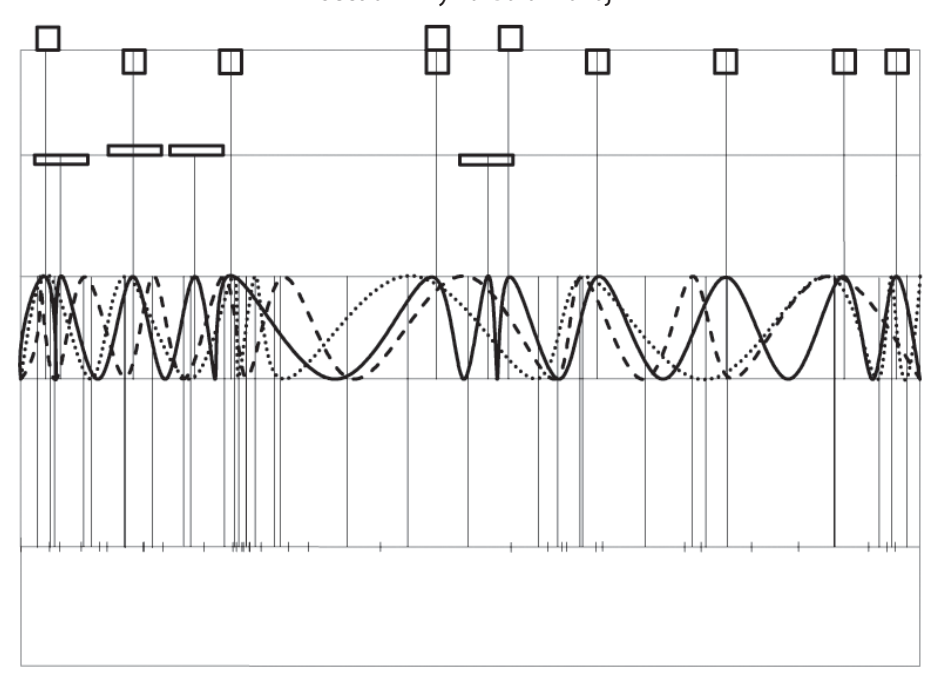

Figure 2. Spatial diversity of landscape, stands and structural units
Amongst the actions aiming to improve road safety conditions, and therefore also to lower the existing stand and structural-landscape unit rhythm, the following can be mentioned to reduce the number of variables: change of the species composition of forest stands, afforest existing open views or the opposite create an open view.

The regional road environment, in comparison with the municipal road, has a much smaller spatial diversity reflected by the distinguished landscape, stand and structural units. Along the analysed fragments of this route, there are 18 intersections (including 4 bi-directional ones) and 4 horizontal curves, with the high-

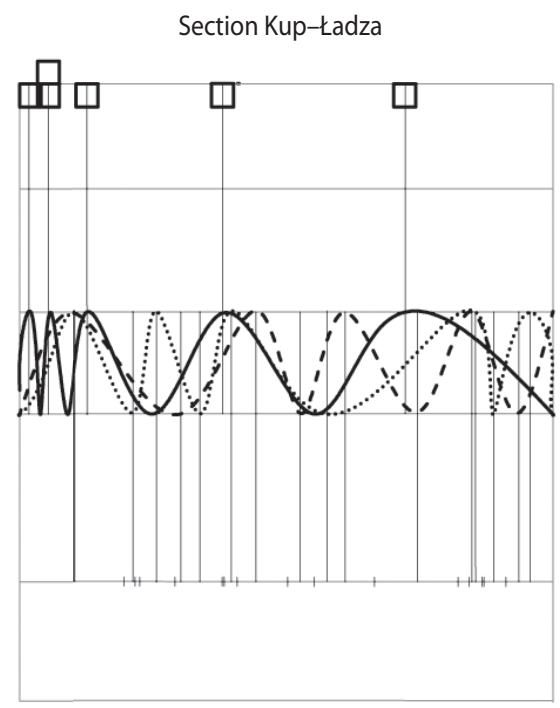

Section Pokój-Zieleniec
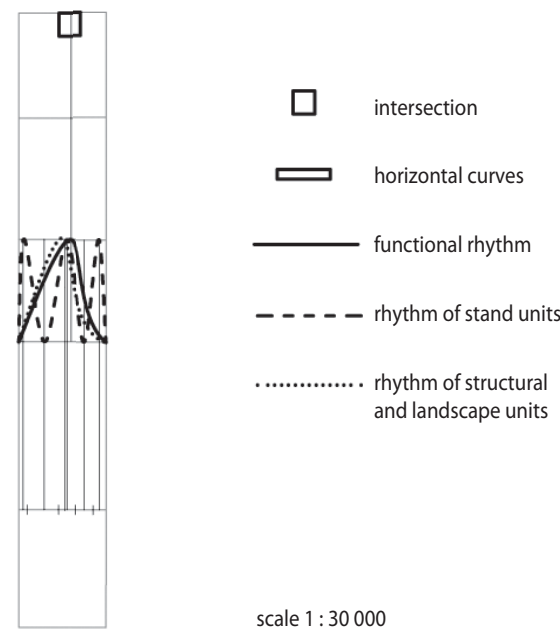

scale $1: 30000$ 
est density of road functional rhythm noticeable in the early parts of sections $B$ and $C$ (Fig. 2). The greatest diversity of rhythm of the structural landscape units occurs in the vicinity of the first three intersections, on section $C$. Such a large number of components in a relatively short road section, in conjunction with a high diversity of tree stands and structural landscape units, requires the introduction of structural changes in the existing environment of the road. First of all, in order to improve safety conditions, the afforestation of the current open view should be considered to decrease the number of structural units, and in turn, 'relax' the road rhythm.

An analysis of the rhythm of the road environment can also be performed for the motorway. The functional rhythm of the studied motorway sections is solely due to the presence of the overpasses. There are no curves here and the road runs in a straight line. Greater spatial differentiation is characterised by section $B$, rather than A. But in the case of this road, because of the fact that all the intersections with other routes are designed to be collision free, altering the landscape is related to improving safety conditions only to a very small degree. The environment of the motorway does not require adjustment of the existing landscape system.

The spatial distribution of landscape, structural and tree stand units was the basis for assessing the attractiveness of forest landscapes in the vicinity of the analysed roads. The analysis of the numerical value of the coefficient of variation for each unit of a particular landscape and determining the maximum and minimum values for particular routes enabled five classes of forest landscape diversity to be established, each with an equal numerical range (Tab. 1).

Table 1. Diversity coefficients of the analysed forest landscapes along the roads

\begin{tabular}{|l|c|c|c|}
\hline \multirow{2}{*}{$\begin{array}{c}\text { Diversity } \\
\text { of landscape } \\
\text { units }\end{array}$} & \multicolumn{3}{|c|}{ Coefficient of variation } \\
\cline { 2 - 4 } & Motorway & Regional road & $\begin{array}{c}\text { Municipal } \\
\text { road }\end{array}$ \\
\hline Very high & $0.040-0.048$ & $0.068-0.081$ & $0.048-0.058$ \\
\hline High & $0.031-0.039$ & $0.054-0.067$ & $0.037-0.047$ \\
\hline Average & $0.022-0.030$ & $0.040-0.053$ & $0.026-0.036$ \\
\hline Small & $0.013-0.021$ & $0.017-0.030$ & $0.015-0.025$ \\
\hline Very small & $0.004-0.012$ & $0.003-0.016$ & $0.004-0.014$ \\
\hline
\end{tabular}

On the basis of the established classes of landscape unit diversity, we found that landscapes with very little variation dominated along the studied roads, whose share of the area along area with very small diversity is lower, though this class still continues to dominate, compared the motorway is $80.2 \%$, along the regional road is $89.6 \%$, and along the municipal road is $74.3 \%$ (Fig. 3 ). The greatest diversity of landscape attractiveness classes was observed along the municipal road. Most areas of high and very high landscape attractiveness occurred along the motorway (a total of 3.6\%). The least area in these classes was found for the regional road $(0.7 \%)$, with a total of $2.8 \%$ of the area along the municipal road.

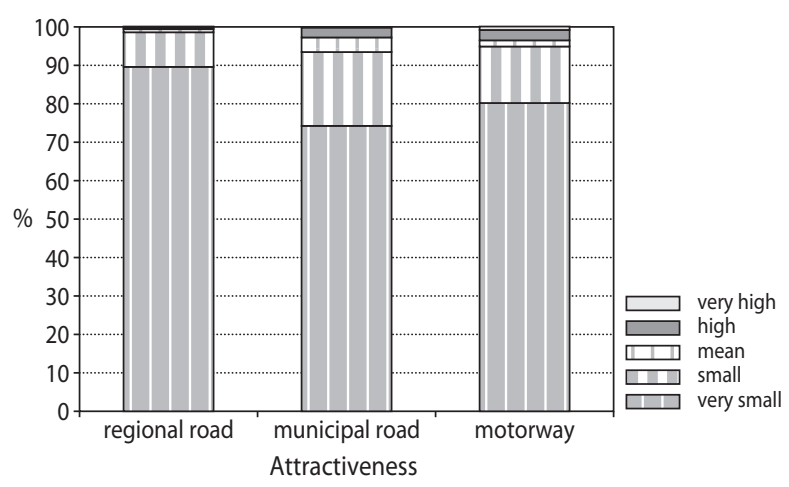

Figure 3. The percentage of landscape attractiveness class for each type of analysed road

\section{Discussion And conclusions}

The purposeful and skillful shaping of the landscape, including the forest landscape, along roads is becoming an increasingly important issue, given the constant and increasingly fast development of the automotive industry, as well as the growing prosperity of societies. Especially of note is that roads routed through an aesthetic environment have lower accident rates and are more willingly used. Decreasing average driving speed in response to the aesthetic surroundings of a road leads to a reduction of approximately $20 \%$ of accident fatalities and about $15 \%$ of accidents with injuries (Kellomäki and Savolainen, 1984).

To maintain the temporal-spatial continuity of planning decisions, methods of assessing the landscape should be used, which take into account classical landscape studies based on the analysis of cartographic materials, relying on specific spatial units. An interesting example of the 
use of landscape units in assessing the landscape are studies on the surroundings of I 90 (interstate A) - the longest Interstate in the United States, connecting Boston with Seattle (Jones et al., 2007). These studies assessed the effect of different variants of the route (e.g. in long/short tunnel and terrain) at 31 key important views, according to a set of four landscape units based on the topography of the area. In a similar way, landscape units are determined in Poland, known as the 'interior landscape' according to the JARK-WAK method of Bogdanowski (1990), as well as method of Borkowski (2003). These methods are useful in the valorisation of open areas, which form a mosaic of different elements of land use (farmland, meadow, forest, etc.) for linear systems, such as river valleys, rail, car and bicycle routes. However, their application in relation to the forest landscape along roads is difficult, mainly because of the evaluation criteria used. A measure of the attractiveness of the forest landscape cannot be the width of a view or the number of visual planes, but only its diversity.

The method presented in this paper is applicable to lowland areas, and its eventual use in mountainous or hilly terrain requires a separate selection of elements, as well as a different determination to be made on how to evaluate specific environmental elements and features. The study results show that in decisions on developing the environs of roads, an analysis of visual variables, primarily the spatial relationships occurring between them (an analysis of the rhythm of the elements comprising the physiognomy of the road and its surrounding area), is of paramount importance. An assessment of the visual attractiveness of the landscape in this context is of secondary significance. Analysing the rhythm of the road and its environment can improve the safety of motor vehicle drivers, especially those roads open for general use, that is, regional and municipal roads. In the case of limited-access public roads (motorways and expressways), opportunities to shape the forest landscape resulting from an analysis of the rhythm of the road and its surroundings are much smaller and only indirectly associated (through a general reference to the aesthetics of the environment) with safety issues.

The forest landscape in the vicinity of roads is an important testing ground for trying out innovative forest management methods, relying to a greater extent than at present on social needs and preferences regarding the aesthetic qualities of the forest. Modifying current rules, methods and techniques of afforestation and forest care and management methods (e.g. design of the forest road network and recreational areas) is possible and becomes even necessary in view of the increasing importance of non-productive forest functions. The adopted methodological assumptions allow a precise range of possibilities to be established for landscaping along roads in a forest that refer to the scale of a specific location. However, there is a need for studies that would determine whether the proposed actions are possible to undertake because of the environmental, cultural and economic conditions of forest management. Moreover, further research is also needed on the factors determining the public's reception, the perception of the forest landscape and the conditions determining its attractiveness. It may be advisable to conduct research to compare the results of an evaluation of landscape attractiveness based on the diversity of landscape elements and landscape preferences. However, this requires the use of the same unit of space - landscape. The framework of the space analysed in maps, in classical studies, must be consistent with the perceptual capabilities of road users, and the distinguished spatial units should take into account variables that are easily identifiable in photographs or videos that depict the route and its surroundings.

\section{References}

Akbar K.F., Hale W.H.G., Headley A.D. 2003. Assessment of scenic beauty of the roadside vegetation in northern England. Landscape and Urban Planning, 63, 139-144.

Arnberger A., Haider W. 2005. Social effects on crowding preferences of urban forest visitors. Urban Forestry and Urban Greening, 3 (3/4), 125-136.

Arriaza M., Canas-Ortega J.F., Canas-Madueno J.A., Ruiz-Aviles P. 2004. Assessing the visual quality of rural landscapes. Landscape and Urban Planning, 69, 115-125.

Bell S. 1997. Design for outdoor recreation. Spon Press 11 New Fetter Lane, London EC4P 4EE.

Bogdanowski J. 1990. Metoda jednostek i wnętrz architektoniczno-krajobrazowych (JARK-WAK) w studiach i projektowaniu. [The method of units and scenic-architectural interiors (JARK-WAK) in study and design]. Politechnika Krakowska, Kraków [in Polish]. 
Borkowski Z. 2003. Ocena atrakcyjności wizualnej ciągu pieszego doliny Marianki [Assessment of visual attractiveness of the pedestrian route in Marianka valley]. Problemy Ekologii Krajobrazu, 11, 177-183 [in Polish].

Clay G.R., Smidt R.K. 2004. Assessing the validity and reliability of descriptor variables used in scenic highway analysis. Landscape and Urban Planning, 66, 239-255.

European Landscape Convention signed in Florence. 2000. https://www.gov.uk/government/uploads/system/uploads/attachment_data/file/236096/8413. pdf. accessed 27 November 2015.

Evans G.W., Wood K.W. 1980. Assessment of environmental aesthetics in scenic highway corridors. Environment and Behavior, 12 (2), 255-273.

Forczek-Brataniec U. 2007. Droga w krajobrazie. Projektowanie dróg z uwzględnieniem czynników otaczającego krajobrazu. [Road in the landscape. Designing roads taking into account the surrounding landscape factors]. Autostrady, 4, 56-64 [in Polish].

Forczek-Brataniec U. 2008. Widok z drogi. Krajobraz $\mathrm{w}$ percepcji dynamicznej. [View from the road. Landscape in the perception of dynamic]. Elamed, Katowice [in Polish].

Gundersen V.S., Frivold L.H. 2008. Public preferences for forest structures: A review of quantitative surveys from Finland, Norway and Sweden. Urban Forestry and Urban Greening, 7 (4), 241-258.

Hammitt W.E., Patterson M.E., Noe F.P. 1994. Identifying and predicting visual preference of southern Appalachian forest recreation vistas. Landscape and Urban Planning, 29, 171-183.

Janeczko E. 2002. Environmental and social determinants of recreational functions of forests Mazowiecki Landscape Park. Ph.D. thesis, SGGW, Warsaw [in Polish].

Janeczko E. 2012. Assessment of forest landscape along some communication routes. Wydawnictwo SGGW, Warsaw [in Polish].

Jensen F.S. 1993. Landscape managers' and politicians' perception of the forest and landscape preferences of the population. Forest and Landscape Research, 1 (1), 79-93.

Jones G.R., Sorey D.F., Scott C.C. 2007. Landscape Architecture Graphic Standards. Hoboken. John Wiley and Sons, New Jersey.
Karjalainen E., Komulainen M. 1999. The visual effect of felling on small- and medium- scale landscapes in north-eastern Finland. Journal of Environmental Management, 55 (3), 167-181.

Kellomäki S., Savolainen R. 1984. The scenic value of forest landscape as assessed in the field and the laboratory. Landscape Planning, 11 (2), 97-107.

Paschalis P. 2009. Leśnictwo a leśna turystyka i rekreacja. [Forestry and forest tourism and recreation]. Studia i Materiaty Centrum Edukacji Przyrodniczo-Leśnej, 4 (23), 29-35 [in Polish].

Polat A.T., Akay A. 2015. Relationships between the visual preferences of urban recreation area users and various landscape design elements. Urban Forestry and Urban Greening, 14 (3), 573-582.

Scrinzi G., Floris A. 2000. Featuring and modelling forest recreation in Italy. Forestry, 73 (2), 173-185.

Śleszyński P. 1997. Z badań nad fizjonomią środowiska przyrodniczego. [From the research on natural environment physiognomy]. Prace i Studia Geograficzne, 21, 255-297 [in Polish].

Sullivan W.C. 1994. Perceptions of the rural-urban fringe. Citizen preferences for nature and developer settings. Landscape and Urban Planning, 29, 85-101.

Tahvanainen L., Tyrvainen L., Ihalainen M., Vuorela N., Kolehmainen O. 2001. Forest management and public perceptions- visual versus verbal information. Landscape and Urban Planning, 53, 53-70.

The National Road Safety Programme GAMBIT, 2005. http://www.krbrd.gov.pl/gambit/gambit_2005.htm. Accessed 27 November 2015.

Tunnard Ch., Pushkarev B. 1963. Man - made America. Chaos or control? Yale University Press, New Haven.

Vander Stoep G.A., Duniavy L. 1992. Public involvement in developing park and open space recreation management strategies. In: Proceedings of the Northeastern Recreation Research Symposium, Gen Tech Rep NE-176, 63-68.

Wójcicki T. 1995. Rules of landscaping in the vicinity of roads. Zeszyty Naukowo-Techniczne Oddziału Stowarzyszenia Inżynierów i Techników Komunikacji w Krakowie, 38.

Wolf K.L. 2003. Freeway roadside management: the urban forest beyond the white line. Journal of Arboriculture, 29 (3), 127-136. 